\title{
Copper nanoparticle-induced ovarian injury, follicular atresia, apoptosis, and gene expression alterations in female rats
}

This article was published in the following Dove Press journal:

International Journal of Nanomedicine

18 August 2017

Number of times this article has been viewed

\author{
Jing Yang ${ }^{1, *}$ \\ Shifu Hu ${ }^{1, *}$ \\ Meng Rao' \\ Lixia $\mathrm{Hu}^{2}$ \\ Hui Lei' \\ Yanqing $\mathrm{Wu}^{\prime}$ \\ Yingying Wang' \\ Dandan $\mathrm{Ke}^{\mathrm{I}}$ \\ Wei Xia ${ }^{1,3}$ \\ Chang-hong Zhu', \\ 'Family Planning Research Institute, \\ Tongji Medical College, Huazhong \\ University of Science and Technology, \\ Wuhan, Hubei, ${ }^{2}$ Department of \\ Histology and Embryology, Preclinical \\ Medicine College, Xinxiang Medical \\ University, Henan Province, Xinxiang, \\ ${ }^{3}$ Reproductive Medicine Center, Tongji \\ Medical College, Huazhong University \\ of Science and Technology, Wuhan, \\ Hubei, People's Republic of China \\ *These authors contributed equally \\ to this work
}

Correspondence: Chang-hong Zhu Family Planning Research Institute, Tongji Medical College, Huazhong University of Science and Technology, Wuhan, Hubei 430030, People's Republic of China Tel/fax +86278369 265।

Email reprodcentre@163.com

\begin{abstract}
Numerous studies have reported the accumulation of copper nanoparticles ( $\mathrm{Cu}$ NPs) in organs and the corresponding damage, although whether $\mathrm{Cu}$ NPs can be translocated to the ovaries and their ovarian toxicity are still unknown. In this study, three groups of female rats were injected with $3.12,6.25$, or $12.5 \mathrm{mg} / \mathrm{kg} \mathrm{Cu}$ NPs for 14 consecutive days. The pathological changes, hormone levels, apoptosis and apoptotic proteins, oxidative stress, and gene expression characteristics in the ovaries were then investigated. The results demonstrated that the Cu NPs exhibited obvious accumulation in the rat ovaries, leading to ovarian injury, an imbalance of sex hormones, and ovarian cell apoptosis. $\mathrm{Cu}$ NP exposure activated caspase 3 , caspase 8 , caspase 9 , and $\mathrm{tBid}$, decreased the protein levels of $\mathrm{Bcl}-2$, increased the expression levels of the proteins Bax and cytochrome $c$, and promoted malondialdehyde (MDA) accumulation and superoxide dismutase (SOD) reduction. Furthermore, gene microarray analysis showed that $\mathrm{Cu}$ NPs $(12.5 \mathrm{mg} / \mathrm{kg} / \mathrm{d})$ caused 321 differentially expressed genes. Of these, 180 and 141 genes were upregulated and downregulated, respectively. $H s d 17 b 1, H_{s} d 3 b 1, H_{s} d 3 b 6$, and $H s d 3 b$ were involved in steroid and hormone metabolism, whereas $M t 3$ and Cebpb were associated with apoptosis. Overall, these findings provide strong evidence that $\mathrm{Cu}$ NPs trigger both intrinsic and extrinsic apoptotic pathways and regulate key ovarian genes in oxidative stress-mediated ovarian dysfunction.
\end{abstract}

Keywords: $\mathrm{Cu}$ NPs, apoptosis, oxidative stress, microarray

\section{Introduction}

When materials are engineered to nanosize with a diameter $<100 \mathrm{~nm}$, they acquire unique physical and chemical properties. Hence, with the rapid development and widespread application of nanoparticles (NPs) in many scientific fields, including cosmetics, the food industry, diagnostic medicine, electronics, and drug delivery, the environmental and occupational exposure of humans to NPs is dramatically increasing. The potential effects of NPs on human health have attracted special attention due to their small size and unique surface area; therefore, the detailed evaluation of their potential risk in vivo is essential.

Copper $(\mathrm{Cu})$ is an essential trace element for the normal growth of humans and animals. ${ }^{1}$ However, if the $\mathrm{Cu}$ intake exceeds the range of biological tolerance, it can exert toxic side effects, including kidney damage, hemolysis, jaundice, and liver and gastrointestinal distress. ${ }^{2,3}$ Copper nanoparticles (Cu NPs), one of the manufactured NPs, are now industrially produced and available commercially. Recently, Cu NP has shown great promise as an antibacterial material ${ }^{4-7}$ and even been used as intrauterine contraceptive device (IUD). ${ }^{8-14}$ Recently, a new type of nano-Cu IUD was invented by 
our research team. The antifertility effectiveness, side effects, and safety of the nano-Cu IUD were extensively studied in rats, mice, rabbits, and rhesus monkeys..$^{8,11,12}$ The results of the experiments showed a high contraceptive efficacy, low side effects, and relative safety. Furthermore, in clinical application, the nano-Cu IUD showed low pregnancy rate, high contraceptive efficacy, and satisfactory acceptability. ${ }^{15}$

However, numerous studies have unequivocally indicated that exposure to $\mathrm{Cu}$ NPs can result in adverse effects in vivo and in vitro. ${ }^{16-20}$ For instance, a previous study demonstrated that the exposure of mice to $\mathrm{Cu}$ NPs resulted in severe kidney, liver, and spleen impairment. ${ }^{16}$ Another study further revealed that the nephrotoxicity of $\mathrm{Cu}$ NPs was highly correlated with significant alterations in the expression of many genes, such as those involved in oxidative phosphorylation, the cell cycle, the mitogen-activated protein kinase signaling pathway, and glutathione metabolism. ${ }^{21}$ In addition, evidence has indicated that $\mathrm{Cu}$ NPs are translocated to the brain and affect neurotransmitter levels, ${ }^{21-23}$ which may influence hormone secretion in the pituitary gland and female reproductive functions.

Recent studies have reported that exposure to some nanomaterials results in reproductive system toxicity. For instance, titanium dioxide NPs are able to accumulate in the ovaries and cause ovarian damage, resulting in an imbalance of mineral element distribution and sex hormones, impaired fertility, and changes in gene expression. ${ }^{24}$ The ovarian injury may be associated with alteration of inflammation-related or follicular-atresia-related cytokine expression. ${ }^{25}$ In addition, gold NPs can enter Chinese hamster ovary cells through the endocytic pathway, ${ }^{26}$ infiltrate rat ovarian granulosa cells and subcellular organelles, and alter in vitro estrogen accumulation. ${ }^{27}$ Moreover, mitogen-activated protein kinase cellular signal transduction pathways in mammalian cells can be activated by silicon carbide nanowires. ${ }^{28}$ Furthermore, evidence has shown that chronic exposure of Enchytraeus albidus worms to $\mathrm{Cu}$ NPs results in lower reproductive output compared to exposure to $\mathrm{CuCl}_{2}$ salt. ${ }^{29}$ The application of $\mathrm{Cu}$ NPs in IUD increases the likelihood of exposure of the general population to $\mathrm{Cu} N P s$; however, whether $\mathrm{Cu}$ NPs can migrate to the ovaries of mammals and affect reproduction has so far remained unclear. Therefore, we hypothesized that the ovaries might also be target organs of toxicity in mammals exposed to $\mathrm{Cu}$ NPs.

In this study, the accumulation of $\mathrm{Cu}$ NPs, ovarian pathological changes, ovarian ultrastructure, expression levels of the apoptotic proteins, oxidative stress, and microarray analysis of the rat ovary were investigated to explore the mechanism of ovarian dysfunction induced by $\mathrm{Cu}$ NPs in rats.

\section{Materials and methods Preparation and characterization of Cu NPs}

$\mathrm{Cu}$ NPs were obtained from $\mathrm{Da} Y u$ Medical Instrument $\mathrm{Co}$ Ltd (Wuhan, Hubei, China). The average particle size and morphology were measured using scanning electron microscopy (SEM). The purity of the Cu NPs was determined by energy-dispersive $\mathrm{X}$-ray spectroscopy (EDS). Hydroxypropyl methylcellulose (HPMC) was obtained from Shanghai Colorcon Coating Technology Limited (Shanghai, People's Republic of China). A 1\% HPMC solution (w/v) was used as the suspending agent. The $\mathrm{Cu}$ NP powder was suspended in $1 \%$ HPMC solution (w/v) inside a specially designed glove box that was filled with dry argon gas to prevent oxidation. To ensure that the $\mathrm{Cu}$ NPs did not aggregate, the solutions containing $\mathrm{Cu}$ NPs were resuspended by sonication for 15-20 $\mathrm{min}$ and mechanical vibration for $2 \mathrm{~min}$, and the time interval from preparation to injection was $<20 \mathrm{~min}$.

\section{Animals and treatment}

Sexually mature female Sprague Dawley rats with an age of 10 weeks and a mean weight of $260 \pm 20 \mathrm{~g}$ were obtained from the Experimental Animal Center of Tongji Medical College, Huazhong University of Science and Technology. The rats were housed in cages under specific-pathogen-free (SPF) conditions. The rats were allowed to acclimatize in an isolated animal room with a 12-h light/dark cycle for at least 5 days before the experiment was carried out. During this period, the conditions were strictly controlled at a constant temperature of $24^{\circ} \mathrm{C} \pm 2^{\circ} \mathrm{C}$ and a relative humidity of $50 \% \pm 10 \%$. The rats were provided with distilled water and sterilized food ad libitum. The Ethical Committee of Tongji Medical College, Huazhong University of Science and Technology approved this research, and the protocols for animal care and treatment were in accordance with their guidelines for animal experiments.

Based on data from the Chen et al ${ }^{16}$ study, the $\mathrm{LD}_{50}$ (median lethal dose) of $\mathrm{Cu}$ NPs in rats is $413 \mathrm{mg} / \mathrm{kg}$ body weight (BW). After acclimatization, the animals were weighed and randomly assigned to four subgroups (each group $\mathrm{n}=6$ ), including a control group receiving $1 \%$ HPMC and three treatment groups that were exposed to $\mathrm{Cu}$ NPs via intraperitoneal injection at doses of 12.5 (Nano-Cu High), 6.25 (Nano-Cu Med), or 3.12 (Nano-Cu Low) mg/kg/d for 14 days. These amounts correspond to human exposures of $\sim 0.03-0.14 \mathrm{~g}$ of $\mathrm{Cu}$ NPs based on a BW of $70 \mathrm{~kg}$. The injection volumes of the $\mathrm{Cu}$ NP suspensions were calculated based on the most recently recorded weights of the rats, and 
the $\mathrm{Cu}$ NPs were administered to the rats by injection every day for 14 days. During the experiment, the animals were examined daily for any clinical signs of toxicity or mortality. BW was measured once every 2 days. After the final administration of $\mathrm{Cu}$ NPs, all of the rats were sacrificed, and blood samples were collected from the eye vein by rapidly removing the eyeball. Serum was collected by centrifuging blood samples at 2,500 rpm for $10 \mathrm{~min}$, and the ovaries were collected and frozen at $-80^{\circ} \mathrm{C}$ for Western blotting, oxidative stress, microarray, and quantitative real-time reverse-transcriptase polymerase chain reaction (qRT-PCR) analyses. The remaining tissues were fixed for histopathological examination and transmission electron microscopy (TEM).

\section{Coefficient of ovary weight to BW}

After weighing the body and ovaries, the coefficient of ovary weight to BW was calculated as ovary weight (wet weight, $\mathrm{mg}) / \mathrm{BW}(\mathrm{g}) \times 100 \%$.

\section{Sex hormone assays}

The levels of sex hormones were evaluated by the serum levels of follicle-stimulating hormone (FSH), luteinizing hormone $(\mathrm{LH})$, progesterone $(\mathrm{P})$, and estradiol $\left(\mathrm{E}_{2}\right)$. All biochemical assays were conducted using a clinical automatic chemistry analyzer (Type 7170A; Hitachi Ltd., Tokyo, Japan).

\section{Histopathological examination and number of mature follicles}

The histological examinations were carried out in compliance with protocols described previously. ${ }^{30}$ The freshly isolated ovarian tissues were fixed with $4 \%$ paraformaldehyde and processed using routine histological techniques. After embedding in paraffin wax, $4 \mu \mathrm{m}$ thick paraffin sections were cut, placed onto glass slides, and stained with hematoxylin and eosin (H\&E) for histopathological observation using a light microscope.

Five typical glides were selected from each ovary. The interval between glides was $>200 \mathrm{~nm}$ to avoid counting follicles repeatedly. The mature follicles are defined as oocytes with three or more layers of cuboidal granulosa cells with antral space. The index of mature follicles was calculated as a percentage of all follicles.

\section{Observation of ovarian ultrastructure using TEM}

The ovaries were dissected and immediately fixed with $2.5 \%$ glutaraldehyde in $0.1 \mathrm{M}$ cacodylate buffer for $2 \mathrm{~h}$.
The samples were then washed three times with $0.1 \mathrm{M}$ cacodylate buffer and postfixed for $2 \mathrm{~h}$ in $1 \%$ osmium tetroxide in $0.1 \mathrm{M}$ cacodylate buffer. The specimens were then washed three times using pure water, dehydrated by a graded ethanol series, and embedded using an EMbed 812 kit by a standard procedure. Ultrathin sections were obtained, double stained with uranyl acetate and lead citrate, and examined by TEM (JEOL/JEM 1400, Japan).

\section{Oxidative stress biomarkers}

Malondialdehyde (MDA) and superoxide dismutase (SOD) levels in the ovarian tissues were determined to assess oxidative stress and damage. The supernatants from ovarian tissue homogenates were obtained according to a method described previously. ${ }^{31}$ Samples of the supernatant were maintained at $4^{\circ} \mathrm{C}$ until determination of their SOD and MDA concentrations using commercial assay kits (Nanjing Jiancheng Institute, Nanjing, Jiangsu, China). All samples were measured in duplicate.

\section{Assessment of apoptosis by TdT-mediated dUTP nick-end labeling (TUNEL) staining} Apoptosis was examined by the TUNEL method. Briefly, ovarian tissues were fixed in $4 \%$ paraformaldehyde, embedded in paraffin, cut into sections with a thickness of $5 \mu \mathrm{m}$, and incubated with the TUNEL kit (Thermo Fisher Scientific, Waltham, MA, USA) in accordance with the manufacturer's instructions, followed by visualization under an inverted fluorescence microscope (Olympus Corporation, Tokyo, Japan). The apoptotic index was calculated as the percentage of TUNEL-positive cells in granulosa cells.

\section{Western blotting}

Western blot analysis was performed according to a previously described method. ${ }^{32}$ The total protein was extracted from ovarian tissue using radioimmunoprecipitation assay buffer (ASPEN, AS1004, Wuhan, Hubei, People's Republic of China), and the protein lysate was separated on $10 \%$ polyacrylamide gels and then transferred to polyvinylidene difluoride (PVDF) membranes. Glyceraldehyde-3-phosphate dehydrogenase (GAPDH) was used as an internal loading control. The blots were visualized with enhanced chemiluminescence (ECL) reagents. The quantitative analysis of each band was performed using ImageJ software (National Institutes of Health, Bethesda, MD, USA). Each experiment was repeated three times and the results were expressed as the average \pm standard deviation (SD). 


\section{Microarray and data analysis}

The gene expression profiles of ovarian tissues isolated from the control rats and those treated with $\mathrm{Cu}$ NPs were compared via microarray analysis using an Illumina BeadChip (Affymetrix, Santa Clara, CA, USA). Briefly, total RNA was extracted using the TRIzol reagent (Thermo Fisher Scientific, Waltham, MA, USA) based on the manufacturer's instructions and stored at $-80^{\circ} \mathrm{C}$. RNA amplification is the standard method for RNA sample preparation for array analysis. ${ }^{33}$ Total RNA was then submitted to Biostar Genechip Inc. (Shanghai, China); a bioanalyzer was used to analyze RNA quality, and cRNA was generated and labeled using the one-cycle target labeling method. The cRNA from each rat was hybridized to a single array based on the standard Illumina RNA Amplification Kit instructions for all arrays. Differentially expressed genes were identified using the Illumina BeadStudio data analysis software (Illumina, Inc., San Diego, CA, USA), and this program established the biological significance according to the Gene Ontology (GO) Consortium (http://www. geneontology.org/GO.doc.html). Student's $t$-test was used to identify differentially expressed genes between the two groups, with an absolute value of $\log 2$-fold change $>1$ and a $P$-value of $<0.05$.

\section{qRT PCR}

The expression levels of $H s d 17 b 1, H s d 3 b 1, H s d 3 b 6, H s d 3 b$, $M t 3$, and $C e b p b$ mRNA in the rat ovaries were quantified using qRT-PCR. GAPDH was included as an internal control, and the gene-specific mRNA expression was normalized to the GAPDH expression. The relative expression of target genes from the real-time PCR results was calculated according to
$2^{-\Delta \Delta C t .}{ }^{34}$ Each treatment was repeated at least three times. The primers for qRT-PCR (Table 1) were designed with Primer Express Software (Applied Biosystems, Foster City, CA, USA) according to the software guidelines.

\section{Statistical analysis}

Statistical analysis was performed using SPSS 20 software (SPSS Inc., Chicago, IL, USA). The results were expressed as the mean \pm SD. Multigroup comparisons of the differences of mean values among the data were carried out using oneway analysis of variance (ANOVA). Statistical significance for all tests was judged at a $P$-value of $<0.05$.

\section{Results}

\section{Physicochemical properties of Cu NPs}

As shown in Figure $1 \mathrm{~A}$ and $\mathrm{B}$, the average size of the $\mathrm{Cu}$ NPs was $\sim 100 \mathrm{~nm}$, and the morphology of the Cu NPs was observed from the SEM image. Furthermore, EDS spectra were used to confirm the presence of $\mathrm{Cu}$, and the results are shown in Figure $1 \mathrm{C}$. The results indicated strong $\mathrm{Cu}$ signals, along with weak oxygen peaks.

\section{General toxicity}

Symptoms of gastrointestinal and mental dysfunction, such as slight diarrhea, anorexia, and drowsiness, were observed in all rats that were administered the $12.5 \mathrm{mg} / \mathrm{kg} / \mathrm{d} \mathrm{Cu} \mathrm{NP}$ dose. No abnormalities were observed in the control group or the other treated groups during the study period.

\section{Coefficient of ovary weight to BW}

The coefficients of ovary weight to $\mathrm{BW}$ for the rats treated with the Cu NPs are presented in Table 2. In the 3.12, 6.25, and

Table I Real-time PCR primer pairs

\begin{tabular}{|c|c|c|c|}
\hline Gene name & Description & Primer sequence & Primer size (bp) \\
\hline \multirow[t]{2}{*}{ GAPDH } & Forward primer $\left(5^{\prime}->3^{\prime}\right)$ & GGCTCTCTGCTCCTCCC & 96 \\
\hline & Reverse primer $\left(5^{\prime}->3^{\prime}\right)$ & CCGTTCACACCGACCTT & \\
\hline \multirow[t]{2}{*}{ Hsdl $7 b \mid$} & Forward primer $\left(5^{\prime}->3^{\prime}\right)$ & AGCGGTTTGTGGAGAAGTAGC & 114 \\
\hline & Reverse primer $\left(5^{\prime}->3^{\prime}\right)$ & GTGGTTATGAGCAAGCCCTGAG & \\
\hline \multirow[t]{2}{*}{$H s d 3 b l$} & Forward primer $\left(5^{\prime}->3^{\prime}\right)$ & СТTССТСТGССССТGСТСТА & 200 \\
\hline & Reverse primer $\left(5^{\prime}->3^{\prime}\right)$ & TTCTGCTTGGCTTCCTCCC & \\
\hline \multirow[t]{2}{*}{$H s d 3 b 6$} & Forward primer $\left(5^{\prime}->3^{\prime}\right)$ & GAAGGCAAGCCAGTAGAGCAG & 166 \\
\hline & Reverse primer $\left(5^{\prime}->3^{\prime}\right)$ & AGACCCCAAGAAGTCACAAAA & \\
\hline \multirow[t]{2}{*}{$H s d 3 b$} & Forward primer $\left(5^{\prime}->3^{\prime}\right)$ & AACTGGAATCAAGGCAGAAGC & 238 \\
\hline & Reverse primer $\left(5^{\prime}->3^{\prime}\right)$ & GCACTCAAGAACAACAGCATAA & \\
\hline \multirow[t]{2}{*}{ Mt3 } & Forward primer $\left(5^{\prime}->3^{\prime}\right)$ & CAGCTCTTCTTGCAGTTCGTG & 81 \\
\hline & Reverse primer $\left(5^{\prime}->3^{\prime}\right)$ & CTGTCCTACTGGTGGTTCCTG & \\
\hline \multirow[t]{2}{*}{ Cebpb } & Forward primer $\left(5^{\prime}->3^{\prime}\right)$ & TAATGCTCGAAACGGAAAAGG & 183 \\
\hline & Reverse primer $\left(5^{\prime}->3^{\prime}\right)$ & GGCCCTGAGTAATCACTTAAA & \\
\hline
\end{tabular}

Note: PCR primers used in the gene expression analysis.

Abbreviation: PCR, polymerase chain reaction. 

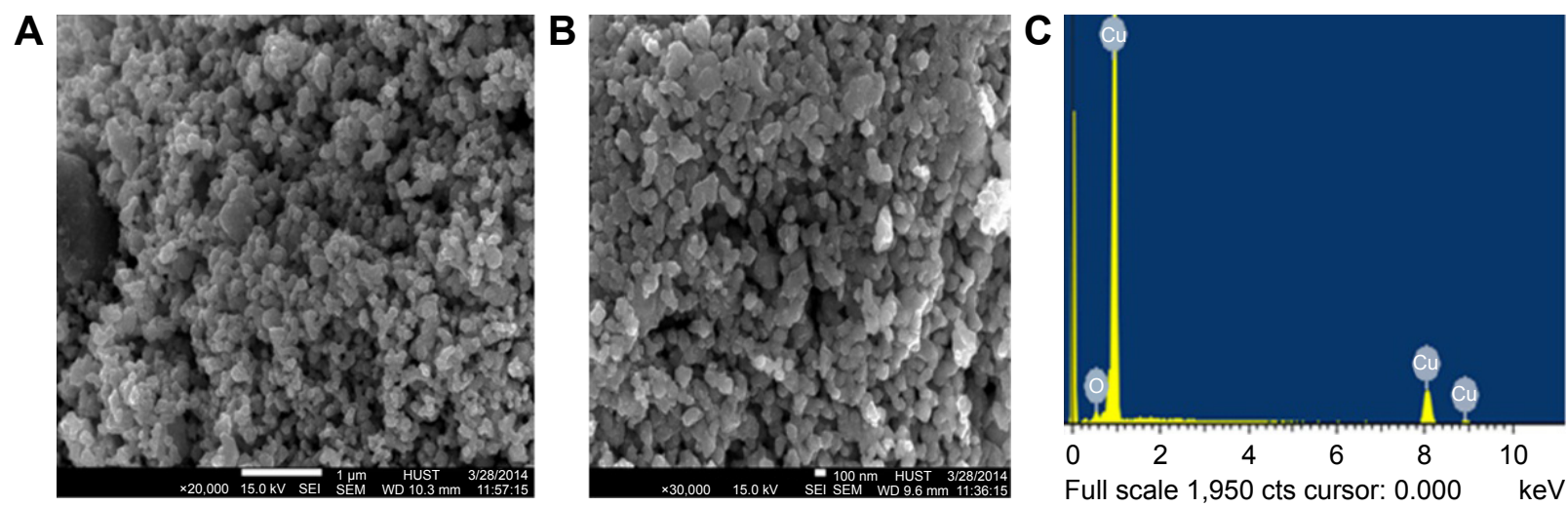

Figure I Physicochemical properties of copper nanoparticles (Cu NPs).

Notes: (A and B) Scanning electron microscopy (SEM) image of Cu NPs, the average size of the particle was I00 nm. (C) Energy dispersive X-ray spectrum (EDS) of Cu NPs. A strong peak at I keV verified the presence of $\mathrm{Cu}$.

$12.5 \mathrm{mg} / \mathrm{kg} / \mathrm{d} \mathrm{Cu} \mathrm{NP}$-treated rats, the coefficients significantly decreased $(P<0.05)$ compared to the control group, indicating ovarian damage in the rats.

\section{Reproductive endocrinology}

The effects of the $\mathrm{Cu}$ NPs on sex hormones in the sera of female rats were examined and are presented in Table 3. The group treated with $12.5 \mathrm{mg} / \mathrm{kg} / \mathrm{d}$ of Cu NPs showed a marked reduction in $\mathrm{FSH}, \mathrm{LH}$, and $\mathrm{P}(P<0.05)$; however, the $\mathrm{E}_{2}$ levels showed no significant changes $(P>0.05)$. In addition, the levels of FSH, LH, $\mathrm{P}$, and $\mathrm{E}_{2}$ exhibited no significant changes for the rats treated with 6.25 or $3.12 \mathrm{mg} / \mathrm{kg} / \mathrm{d}$ of $\mathrm{Cu}$ NPs compared to the control group.

\section{Histopathological evaluation and mature follicles}

The ovarian histopathological changes are shown in Figure 2. In comparison to the control group, significant ovarian histopathological changes were observed for the rats treated with high-dose $(12.5 \mathrm{mg} / \mathrm{kg} / \mathrm{d}) \mathrm{Cu}$ NPs (Figure 2B), including ovarian atrophy, disturbance of follicular development, follicular atresia, and reduction in mature follicles. No severe damage to the ovarian tissue was observed for the 6.25 and

Table 2 Effects of nano-Cu on organ coefficient in female rats $($ mean $\pm \mathrm{SD})$

\begin{tabular}{lll}
\hline Group & $\mathbf{n}$ & $\begin{array}{l}\text { Ovary indices } \\
(\mathbf{g} / \mathbf{g} \times 1 \mathbf{1 0 0})\end{array}$ \\
\hline I\% HPMC & 6 & $0.045 \pm 0.005$ \\
Nano-Cu high & 6 & $0.024 \pm 0.004^{*}$ \\
Nano-Cu med & 6 & $0.030 \pm 0.004^{*}$ \\
Nano-Cu low & 6 & $0.024 \pm 0.003^{*}$ \\
\hline
\end{tabular}

Note: $* P<0.05$ when compared with control group

Abbreviations: $\mathrm{Cu}$, copper; med, medium; HPMC, hydroxypropyl methylcellulose; SD, standard deviation.
$3.12 \mathrm{mg} / \mathrm{kg} / \mathrm{d} \mathrm{Cu} \mathrm{NP}$ treatment groups (Figure 2C and D). Moreover, the $12.5 \mathrm{mg} / \mathrm{kg} / \mathrm{d} \mathrm{Cu} \mathrm{NP}$ exposure group resulted in significant decreases in the percentage of mature follicles $(P<0.05)$ (Figure 3).

\section{Observation of ovarian ultrastructure}

The TEM images of the ovarian cell ultrastructure are presented in Figure 3. The ultrastructure of ovarian cells of the control group rats can be considered the normal cell structure (Figure 4A). In contrast, the ultrastructure of ovarian cells exposed to the high-dose $\mathrm{Cu}$ NPs $(12.5 \mathrm{mg} / \mathrm{kg} / \mathrm{d})$ exhibited irregularity of the nuclear membrane, mitochondrial swelling, and cristae breakage (Figure 4B). Additionally, as shown in Figure $4 \mathrm{C}$ and D, the Cu NPs agglomerated in the cytoplasm of ovarian cells, suggesting that they were deposited in the ovarian cells. These results indicated that high-dose $\mathrm{Cu}$ NPs induced overt ovarian dysfunction in rats.

\section{Oxidative stress analysis}

To determine the effects of the various doses of Cu NPs on oxidative stress indices in rat ovarian tissues, the levels of SOD and MDA were analyzed. As shown in Table 4, exposure to $12.5 \mathrm{mg} / \mathrm{kg} / \mathrm{d}$ of Cu NPs caused a significant reduction in SOD activities $(P<0.05)$, while the concentrations of MDA were significantly increased $(P<0.05)$; however, compared to the control group, no significant changes in SOD or MDA levels were observed in the groups treated with 6.25 or $3.125 \mathrm{mg} / \mathrm{kg} / \mathrm{d}$ of Cu NPs $(P>0.05)$.

\section{Effect of Cu NPs on DNA strand breakage}

As shown in Figure 5, the TUNEL assay was used for the detection of apoptosis in granulosa cells in rats of all the four groups. TUNEL-positive cells were observed in the granulosa 
Table 3 Effects of nano-Cu on serum hormone level in female rats (mean \pm SD)

\begin{tabular}{|c|c|c|c|c|c|}
\hline Group & $\mathbf{N}$ & FSH $(\mathrm{mlU} / \mathrm{mL})$ & LH $(\mathrm{mlU} / \mathrm{mL})$ & $P(\mathrm{ng} / \mathrm{mL})$ & $E_{2}(p g / m L)$ \\
\hline I\% HPMC & 6 & $1.93 \pm 0.11$ & $3.28 \pm 0.27$ & $12.56 \pm 0.67$ & $9.94 \pm 0.7$ \\
\hline Nano-Cu high & 6 & $|.26 \pm 0.3| *$ & $2.18 \pm 0.3 I^{*}$ & $9.55 \pm 0.46 *$ & $9.97 \pm 0.47$ \\
\hline Nano-Cu med & 6 & $1.77 \pm 0.21$ & $2.5 \mathrm{I} \pm 0.43$ & $10.58 \pm 0.58^{*}$ & $9.8 \pm 0.62$ \\
\hline Nano-Cu low & 6 & $1.83 \pm 0.15$ & $3.09 \pm 0.16$ & $11.92 \pm 0.94$ & $10.11 \pm 0.72$ \\
\hline
\end{tabular}

Note: *Values differ significantly from control $(P<0.05)$.

Abbreviations: $\mathrm{Cu}$, copper; $\mathrm{E}_{2}$, estradiol; $\mathrm{FSH}$, follicle-stimulating hormone; HPMC, hydroxypropyl methylcellulose; $\mathrm{LH}$, luteinizing hormone; med, medium; $\mathrm{P}$, progesterone; $\mathrm{SD}$, standard deviation.

cells, and $\mathrm{Cu} \mathrm{NP}$ exposure resulted in significant increases in the percentage of apoptotic cells compared with the control $(P<0.05)$ (Figure 6).

\section{Apoptosis-related protein expression in ovaries}

To investigate whether $\mathrm{Cu}$ NPs induced apoptosis and ovarian injury, the expression levels of apoptosis-related proteins (caspase 3, caspase 8, caspase 9, cytochrome $c$, Apaf-1, tBid, Bcl-2, and Bax) were examined in the ovarian tissues from rats with or without exposure to $\mathrm{Cu}$ NPs. As shown in Figure 7, our results showed that the expression levels of caspase 8 , caspase 3 , and caspase 9 proteins in the ovaries were significantly promoted by the different doses of $\mathrm{Cu}$ NPs $(12.5,6.25$, and $3.125 \mathrm{mg} / \mathrm{kg} / \mathrm{d})$ in comparison with the control. Furthermore, the Cu NPs induced dramatic increases in the expression of $\mathrm{Bax}, \mathrm{tBid}$, cytochrome $c$, and Apaf-1, and the expression of Bcl-2 was obviously suppressed by $\mathrm{Cu}$ NPs.

\section{Gene expression profile}

The global gene expression profiling using mRNAs from ovarian tissues, including the control group and the rats treated with $12.5 \mathrm{mg} / \mathrm{kg} / \mathrm{d} \mathrm{Cu} \mathrm{NPs}$, was analyzed using a microarray. The treated group was compared with the vehicle control under these criteria: $\log 2$-fold change $>1$ or $<1$ and $P<0.05$. The results showed that 321 genes were significantly changed following $\mathrm{Cu}$ NP treatment. Of the altered genes, 180 and 141 genes were upregulated (Table S1) and downregulated (Table S2), respectively. According to the
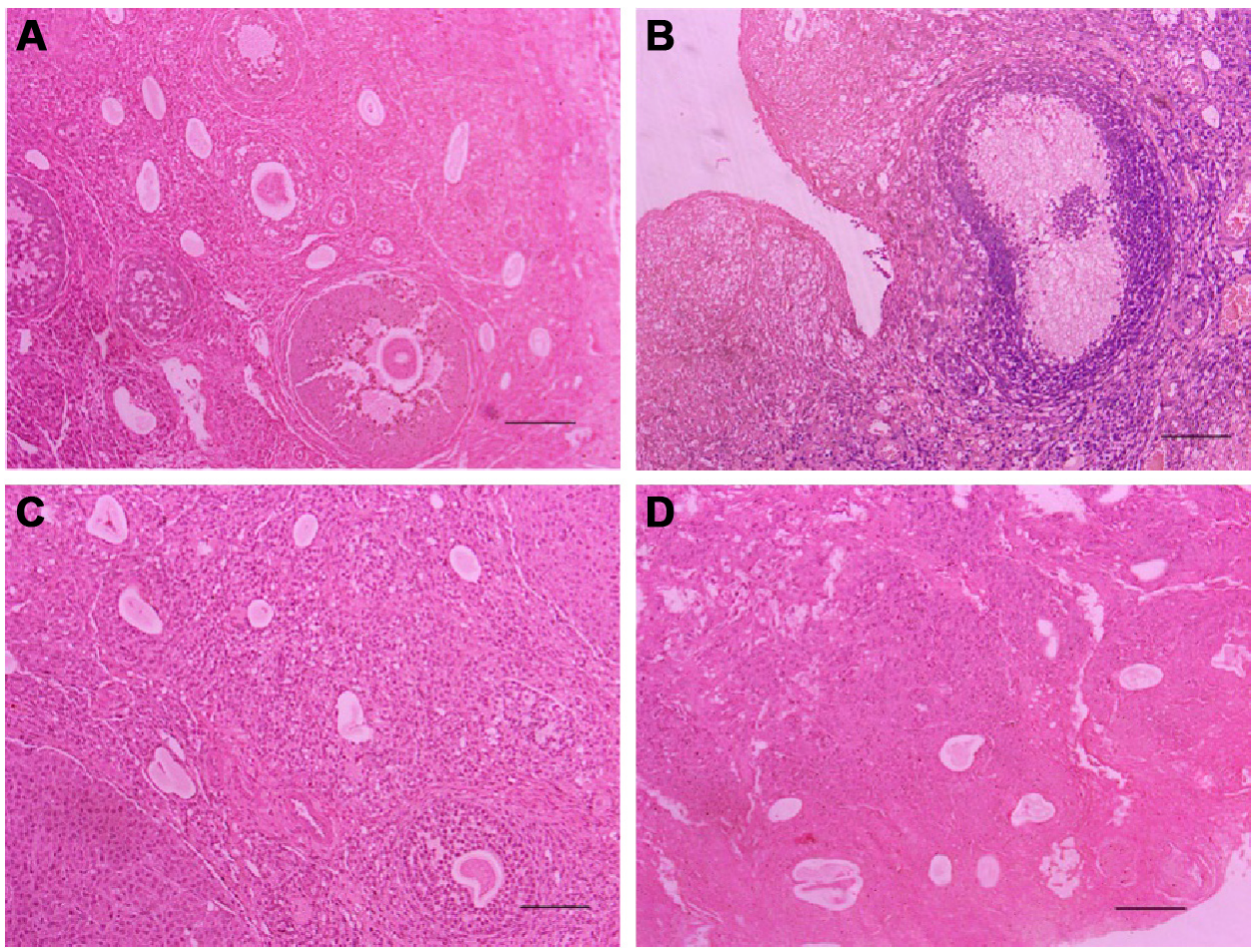

Figure 2 Histopathological observation of ovary caused by intraperitoneal injection with Cu NPs for 14 days.

Notes: (A) Control group presents normal; (B) 12.5 mg/kg/d Cu NP-treated group: ovarian atrophy and follicular atresia; (C) $6.25 \mathrm{mg} / \mathrm{kg} / \mathrm{d}$ Cu NP-treated group presents basically normal; and (D) $3.12 \mathrm{mg} / \mathrm{kg} / \mathrm{d}$ Cu-NP-treated group shows normal.

Abbreviation: Cu NPs, copper nanoparticles. 


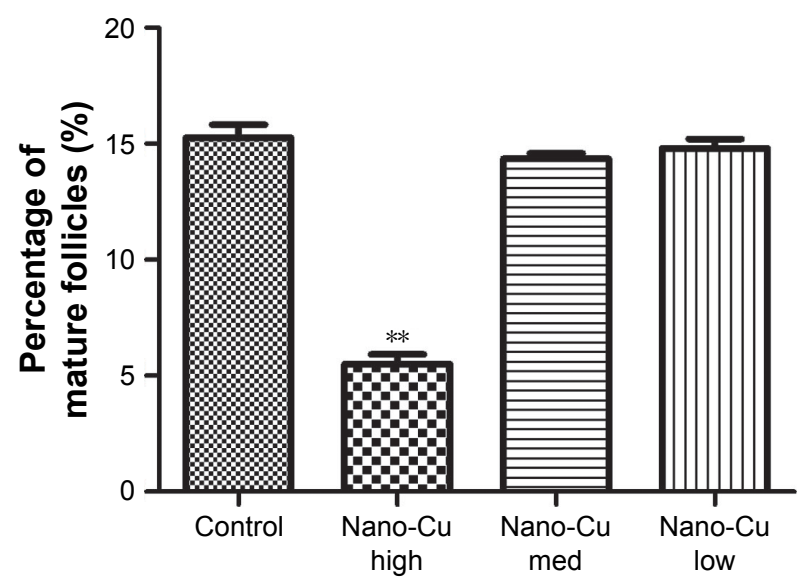

Figure 3 Number of mature follicles in ovaries after rats were treated with different doses of Cu NPs.

Notes: Values are expressed as mean $\pm S D, n=6$. $* * p<0.01$ : when compared with control group.

Abbreviations: $\mathrm{Cu}$, copper; $\mathrm{Cu}$ NPs, copper nanoparticles; med, medium; SD standard deviation.

GO analysis, these genes were closely involved in oxidative stress, the cell cycle, steroid hormone biosynthesis, apoptotic processes, cell proliferation, stress responses, signal transduction, and so on (Figure 8).

\section{qRT-PCR}

To validate the accuracy of the microarray results, several genes with significantly different expression patterns, including $H s d 17 b 1, H s d 3 b 1, H s d 3 b 6, H s d 3 b, M t 3$, and $C e b p b$, were further investigated using qRT-PCR due to their association with steroid biosynthetic processes and apoptosis. The $H s d 17 b 1$ and $M t 3$ genes were upregulated, whereas $H s d 3 b 1$, $H s d 3 b 6, H s d 3 b$, and Cebpb were downregulated. The qRTPCR analysis of all genes displayed expression patterns consistent with the microarray data (ie, either upregulation or downregulation; Table 5).

\section{Discussion}

To the best of our knowledge, this is the first study to focus on the effect of $\mathrm{Cu}$ NPs on reproductive toxicity in vivo. Our findings indicated that intraperitoneal injection of $12.5 \mathrm{mg} / \mathrm{kg} / \mathrm{d} \mathrm{Cu}$ NPs for 14 consecutive days led to overt toxicity. Exposure to $\mathrm{Cu}$ NPs can decrease the coefficient of ovary weight to BW and accumulate in the ovaries, which in turn induces follicular atresia and apoptosis. Moreover, we observed irregularity of the nuclear membrane, mitochondrial
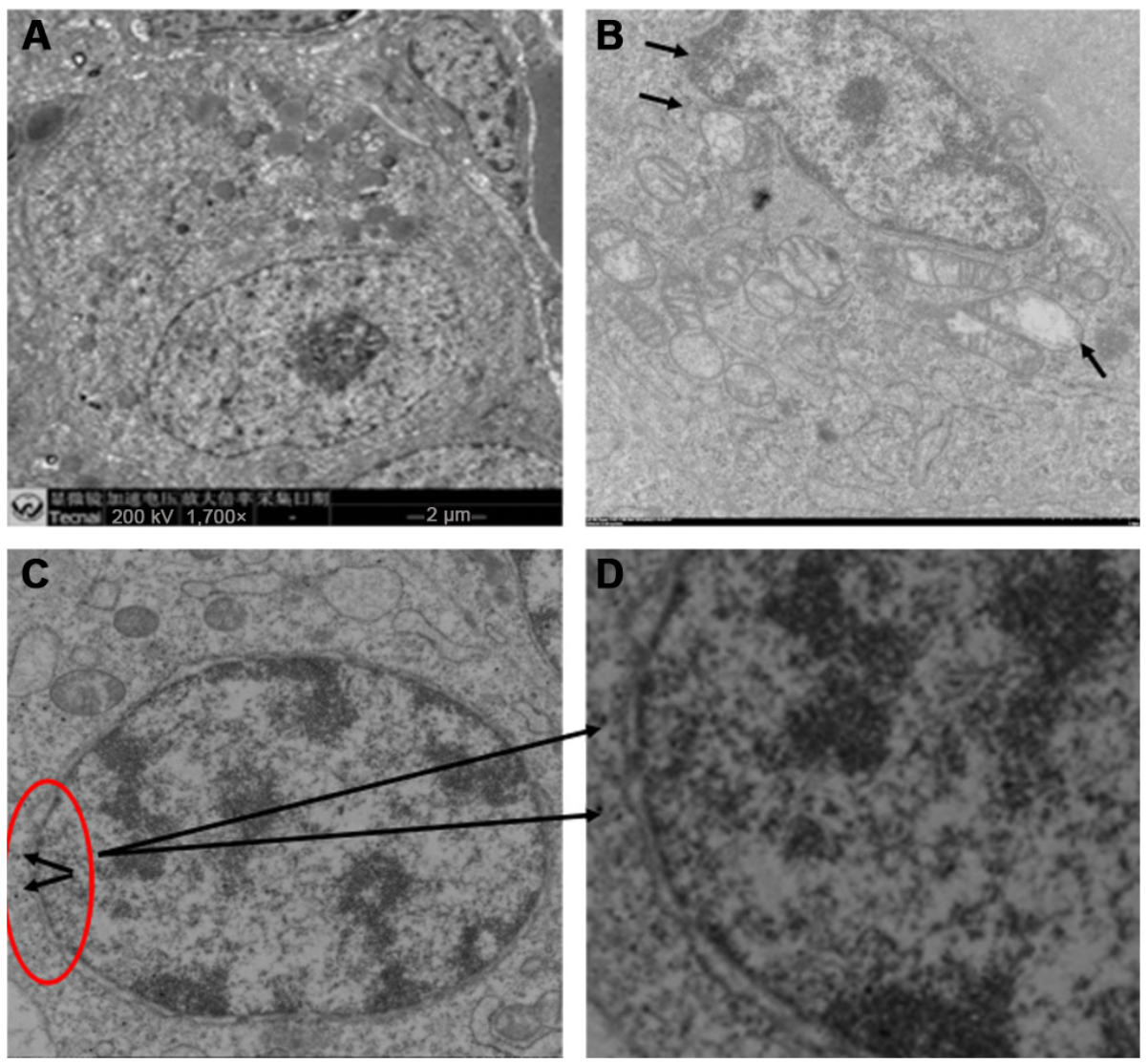

Figure 4 Ultrastructure of ovarian cell in female rats caused by intraperitoneal injection with Cu NPs for 14 days.

Notes: (A) Control group: nucleus with homogeneous chromatin, mitochondria turn complete in ovarian cell; (B) $12.5 \mathrm{mg} / \mathrm{kg} / \mathrm{d}$ Cu NP-exposed group: mitochondria swelling, irregularity of the nuclear membrane, and cristae breakage. (C and D) $12.5 \mathrm{mg} / \mathrm{kg} / \mathrm{d}$ Cu NP-exposed group: Cu NP deposition in ovarian cell. The arrows represent mitochondria swelling, irregularity of the nuclear membrane, and cristae breakage.

Abbreviation: Cu NPs, copper nanoparticles. 
Table 4 Effects of nano-Cu on oxidative stress related biomarkers in ovary

\begin{tabular}{llll}
\hline Group & $\mathbf{n}$ & SOD (U/mg prot) & MDA (nmol/mg prot) \\
\hline I\% HPMC & 6 & $149.3 \pm 5.77$ & $0.26 \pm 0.04$ \\
Nano-Cu high & 6 & $135.47 \pm 3.5^{*}$ & $0.41 \pm 0.07^{*}$ \\
Nano-Cu med & 6 & $140.17 \pm 5.08$ & $0.34 \pm 0.06$ \\
Nano-Cu low & 6 & $145.63 \pm 1.62$ & $0.27 \pm 0.03$ \\
\hline
\end{tabular}

Notes: *Values differ significantly from control $(P<0.05)$. Data presented as mean \pm SD.

Abbreviations: $\mathrm{Cu}$, copper; HPMC, hydroxypropyl methylcellulose; MDA, malondialdehyde; med, medium; prot, protein; SOD, superoxide dismutase.

swelling, and cristae breakage. The mitochondrial swelling indicated that $\mathrm{Cu}$ NPs enter the cell, bind to the mitochondria, and result in structural changes to the mitochondria and subsequent effects.

Our findings indicated that the folliculogenesis inhibition and ovarian damage may be triggered by $\mathrm{Cu}$ NPs altering female hormone levels and ovarian gene expression, the activation of apoptogenic factors and apoptosis-inducing factor, and reactive oxygen species (ROS) accumulation. This led to the disruption of ovarian tissue and apoptosis. Therefore, we considered the possible mechanisms of the in vivo ovarian damage caused by treatment with $\mathrm{Cu}$ NPs.

According to Amorim et al, ${ }^{29}$ chronic exposure of E. albidus worms to $\mathrm{Cu}$ NPs resulted in lower reproductive output compared to exposure to $\mathrm{CuCl}_{2}$ salt. Follicular development is closely related to levels of sex hormones. Gao et $\mathrm{al}^{24}$ reported that exposure to $\mathrm{TiO}_{2} \mathrm{NPs}$ significantly decreased serum levels of $\mathrm{P}, \mathrm{LH}, \mathrm{T}$, and FSH and increased the concentration of $\mathrm{E}_{2}$. In partial agreement with that study, our results showed that exposure to $\mathrm{Cu}$ NPs significantly decreased serum concentrations of FSH, LH, and $\mathrm{P}$ and had no effect on the secretion of $\mathrm{E}_{2}$. It is known that $\mathrm{E}_{2}$ plays a vital role in regulating the differentiation of granulosa cells and gonadotropin secretion, ${ }^{35}$ and FSH and LH are the main components of the hypothalamic-pituitary-gonadal axis and play a critical role in regulating reproductive function. In female reproduction, $\mathrm{P}$ plays pivotal roles in ovulation, implantation, and maintenance of pregnancy. ${ }^{36}$ Therefore, the
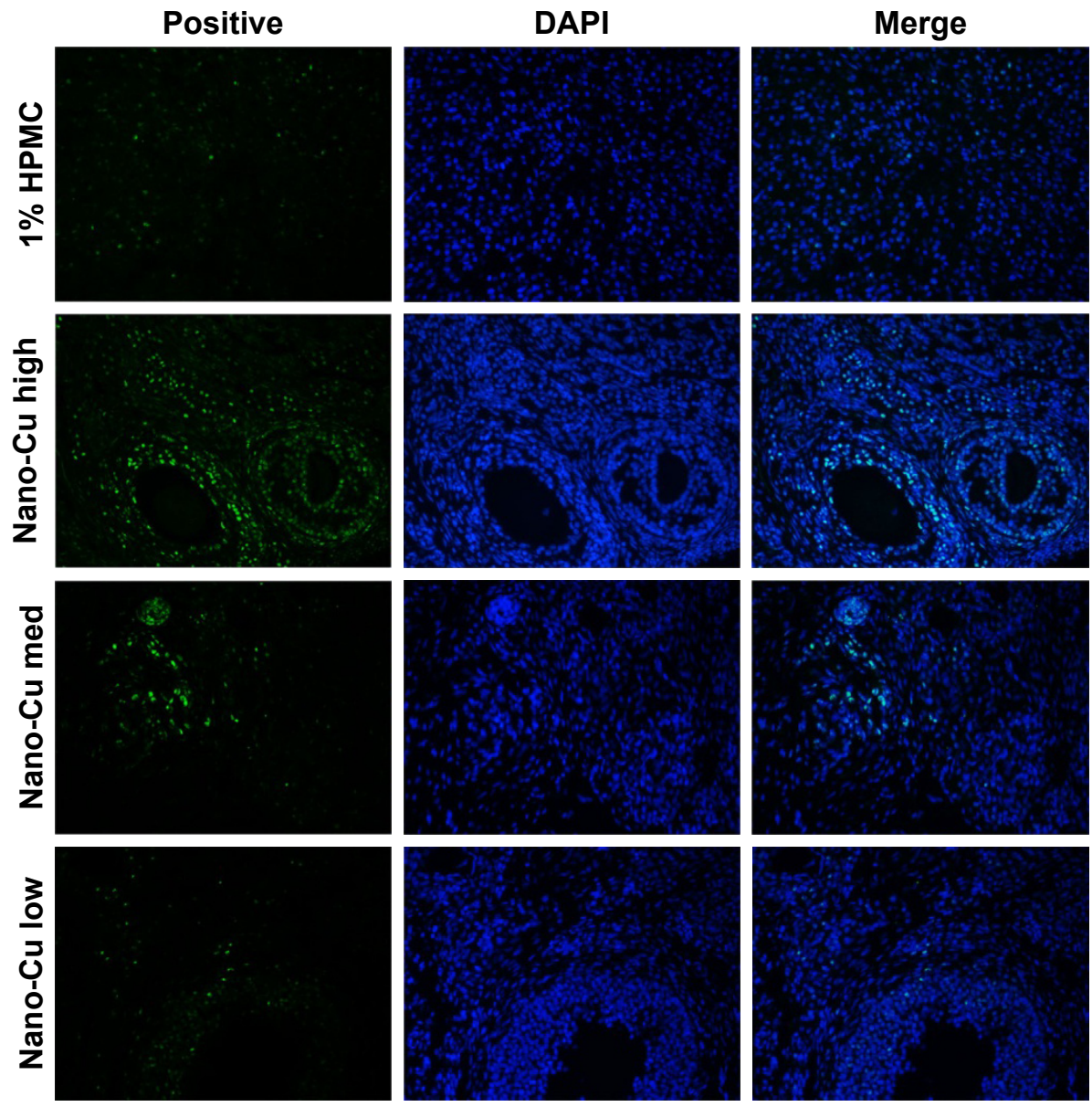

Figure 5 Increased TUNEL positive apoptotic granulosa cells of ovarian tissues in Cu NP-treated rats.

Notes: The apoptotic cells are shown as green fluorescence with fluorescein isothiocyanate staining. The nucleus was stained with DAPI (original magnification 200x). Abbreviations: $\mathrm{Cu}$, copper; Cu NPs, copper nanoparticles; DAPI, 4,6-diamidino-2-phenylindole; HPMC, hydroxypropyl methylcellulose; med, medium; TUNEL, TdTmediated dUTP nick-end labeling. 


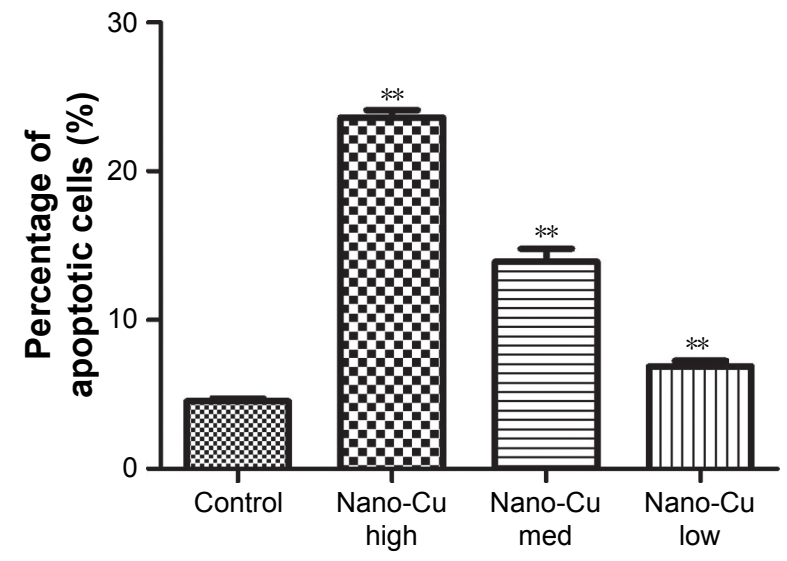

Figure 6 Percentages of apoptotic cells in ovaries after rats were exposed to different doses of Cu NPs.

Notes: Values are expressed as mean $\pm S D, n=6$. $* * p<0.01$ : when compared with control group.

Abbreviations: $\mathrm{Cu}$, copper; $\mathrm{Cu} N \mathrm{~N}$ s, copper nanoparticles; med, medium; SD, standard deviation.

inhibition of follicular development and follicular atresia caused by $\mathrm{Cu} \mathrm{NP}$ exposure were associated with the alteration of FSH, LH, and P levels.

Follicular atresia is not only the breakdown of ovarian follicles but also a kind of cell apoptosis. As the TUNEL assay is considered a reliable method for the evaluation of apoptosis, we used this technique to verify apoptosis and this revealed that $\mathrm{Cu}$ NPs induced apoptotic cell death in ovarian tissue.
Oxidative stress has been associated with induction of cell death by apoptosis or necrosis. ${ }^{37-39}$

To further verify ovarian apoptosis, we examined SOD production and MDA accumulation in the ovaries. Oxidative stress and lipid peroxidation have been shown to be important mechanisms of cytotoxicity associated with NPs. ${ }^{38}$ Our results indicated that the levels of MDA, a product of lipid peroxidation, were significantly higher in the ovaries of the rats treated with the $\mathrm{Cu}$ NPs, whereas the levels of the antioxidant SOD were significantly lower, suggesting that the ovaries of the rats treated with $\mathrm{Cu}$ NPs had undergone severe oxidative stress. These results were in agreement with previous studies. For instance, Wang et $\mathrm{al}^{40}$ demonstrated that exposure to $\mathrm{Cu}$ NPs significantly increased ROS and MDA levels in hepatocytes and decreased the total superoxide dismutase (T-SOD) activity. Another work indicated that exposure to nano- $\mathrm{Cu}$ increased the production of ROS and induced oxidative stress and apoptosis in kidney tissue. ${ }^{41}$ In our study, an increase in lipid peroxidation and disruption of the antioxidant system in the ovaries following exposure to $\mathrm{Cu}$ NPs were verified by the enhancement of MDA and the reduction of SOD, respectively. Therefore, we speculated that the process of ovarian apoptosis induced by $\mathrm{Cu}$ NPs may be mediated by the mitochondria-initiated pathway. ${ }^{42,43}$
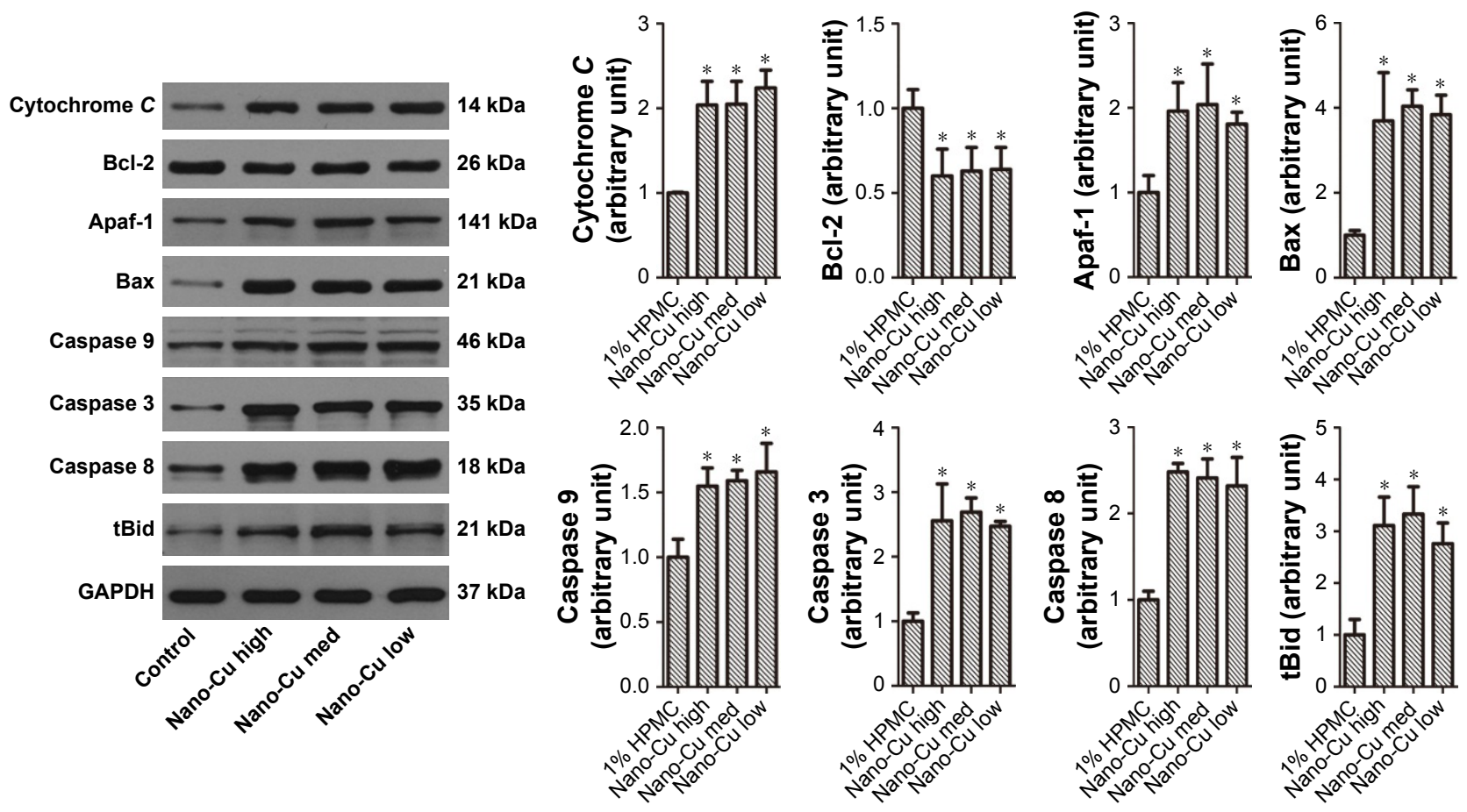

Figure 7 Western blot analysis of Cyt c, Bcl-2, Apaf-I, Bax, caspase 9, caspase 3, caspase 8, and tBid in ovarian tissue treated with Cu NPs.

Note: $* P<0.05$ when compared with control group.

Abbreviations: Cu NPs, copper nanoparticles; HPMC, hydroxypropyl methylcellulose; med, medium. 
Antigen processing and presentation -

Collecting duct acid secretion -

Ovarian steroidogenesis -

Circadian rhythm -

Alpha-linolenic acid metabolism -

Ether lipid metabolism -

Steroid hormone biosynthesis -

Glycerophospholipid metabolism -

Epstein-barr virus infection -

Herpes simplex infection

Autoimmune thyroid disease

Type I diabetes mellitus

Viral myocarditis

Allograft rejection -

Graft-versus-host disease

Viral carcinogenesis -

HTLV-I infection -

Spliceosome -

Cell adhesion molecules (CAMs) -

p53 signaling pathway

Cell cycle

Phagosome

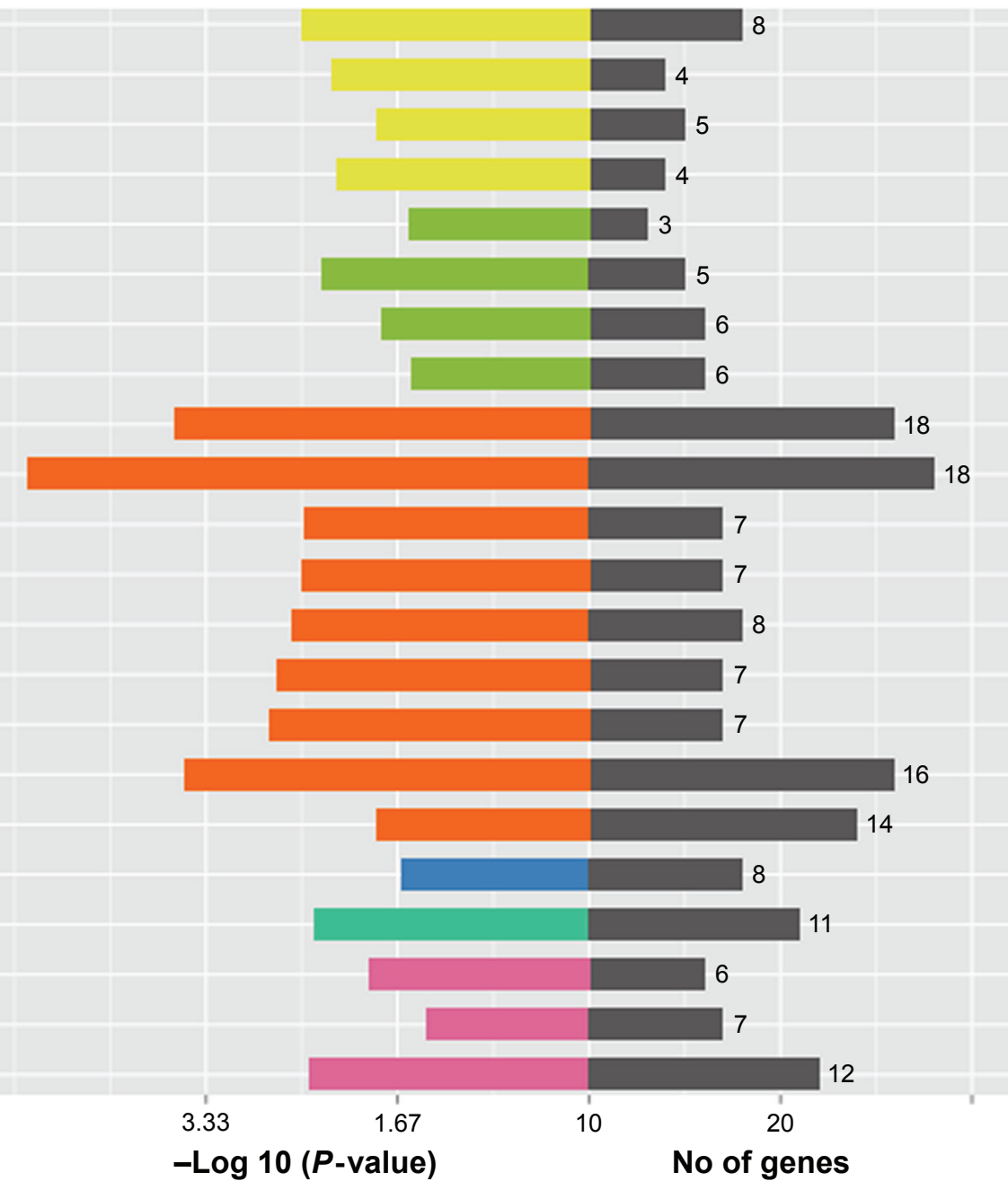

\begin{tabular}{|c|c|c|c|}
\hline \multicolumn{4}{|l|}{ Classification } \\
\hline Organismal systems & Metabolism & Human diseases & Genetic information processing \\
\hline Environmental inform & processing & Cellular processe & \\
\hline
\end{tabular}

Figure 8 Functional classification of genes.

Notes: Kyoto encyclopedia of genes and genomes (KEGG) enrichment analysis of differently expressed genes. The black color represents the number of genes corresponding to different classifications.

Abbreviation: HTLV, human T-lymphotropic virus.

Table 5 Real-time quantitative RT-PCR validation of selected genes from microarray data in Cu NP-treated groups

\begin{tabular}{|c|c|c|c|}
\hline & $\Delta \Delta \mathrm{Ct}$ & Fold & Microarray \\
\hline$H s d \mid 7 b l$ & -1.32428 & 2.504078865 & 2.04302158 \\
\hline$H s d 3 b l$ & 0.628622 & $0.6467939 \mid$ & 0.396295195 \\
\hline$H s d 3 b 6$ & 0.54286 & 0.686408822 & 0.398208713 \\
\hline$H s d 3 b$ & 0.84284 & 0.55754484 & 0.396295195 \\
\hline Mt3 & -2.14562 & 4.424823778 & 3.303252354 \\
\hline Cebpb & 0.528 & $0.6935 \mid 5485$ & 0.441516324 \\
\hline
\end{tabular}

Note: Values represent mean $(\mathrm{N}=3)$.

Abbreviations: Cu NPs, copper nanoparticles; RT-PCR, reverse-transcriptase polymerase chain reaction.
Furthermore, apoptosis, or programmed cell death, is a genetically controlled and highly organized type of cell death that can be mediated by different stimuli via two main signaling pathways: the mitochondria-initiated intrinsic pathway and the death-receptor-mediated extrinsic apoptotic pathway, which triggers a cascade reaction mediated by caspase 8 activation..$^{28,44,45}$ The evidence suggests that the Bcl-2 family proteins, including pro-apoptotic proteins (eg, Bax and tBid) or antiapoptotic protein (eg, Bcl-2), can be regarded as crucial elements of mitochondria-mediated apoptosis. ${ }^{46-48}$ When 
the expression of Bcl-2 protein is decreased and the expression of Bax protein is increased, mitochondrial membrane potential declines due to the destruction of the mitochondrial membrane. This contributes to the release of cytochrome $c$ from the mitochondria to the cytosol. Then, a cascade reaction occurs, which includes cytochrome binding with Apaf-1 resulting in the activation of the initiator caspase 9 and triggering the activation of the effector caspase 3 . It has been well established that nano- $\mathrm{Cu}$ triggers both extrinsic and intrinsic apoptotic pathways in oxidative stress-mediated kidney injury. ${ }^{41}$ Similarly, our study confirmed that $\mathrm{Cu}$ NPs induced mitochondria-initiated intrinsic cell death. Our results showed that the rats treated with $\mathrm{Cu}$ NPs exhibited downregulation of $\mathrm{Bcl}-2$ proteins and upregulation of the Bax protein, leading to the release of cytochrome $c$ from the mitochondria to the cytosol. Furthermore, $\mathrm{Cu} \mathrm{NP}$ exposure induced the expression of cytochrome $c$, Apaf-1, caspase 9 , and caspase 3 and also significantly increased caspase 8 and tBid levels. Taken together, our results strongly indicate that $\mathrm{Cu}$ NPs induce apoptosis in the ovaries via both extrinsic and intrinsic pathways.

$\mathrm{Cu}$ NP-induced ovarian injury and hormonal changes in female rats may be associated with the alterations in ovarian gene expression. Therefore, we analyzed microarray data and found that 321 genes (180 upregulated and 141 downregulated) were significantly altered by exposure to $\mathrm{Cu}$ NPs, and these genes were involved in oxidative stress, the cell cycle, steroid biosynthetic processes, the apoptotic process, cell proliferation, stress responses, signal transduction, and so on. Many genes are critical for the apoptotic process, such as $M t 3$ and Cebpb. Interestingly, our data showed that Mt3 was significantly upregulated and $C e b p b$ was obviously downregulated in the ovaries of rats treated with $12.5 \mathrm{mg} / \mathrm{kg} / \mathrm{d}$ of Cu NPs. Moreover, increased expression of $M t 3$ and decreased expression of $C e b p b$ were further verified by qRT-PCR. Evidence has shown that metallothioneins (MTs) play vital roles in protecting against DNA damage and apoptosis, and these proteins are often divided into four classes (MT1-4). ${ }^{49}$ MT3 has been identified as a growth inhibitor factor that could inhibit neuritis formation and survival in neurons. ${ }^{50}$ Overexpression of MT3 may inhibit proliferation and induce apoptosis. ${ }^{37}$ The transcription factor of the leucine zipper basic region CCAAT/enhancer-binding protein $b(\mathrm{C} / \mathrm{EBPB})$ is a member of the $\mathrm{C} / \mathrm{EBP}$ family. ${ }^{51-54}$ Evidence has indicated that $\mathrm{C} / \mathrm{EBPB}$ regulates cell differentiation, survival, proliferation, and metabolic processes by inhibition or activation of the target genes. A recent study showed that cells underwent accelerated apoptosis in Cebpbdeficient mice. ${ }^{55}$ Therefore, increased Mt3 and decreased $C e b p b$ expression upon exposure to $\mathrm{Cu}$ NPs may induce apoptosis and follicular atresia in the ovaries.

Furthermore, some of the pathways identified through the kyoto encyclopedia of genes and genomes (KEGG) pathway analysis are associated with viral diseases. In this study, our rats were treated with $\mathrm{Cu}$ NPs, the reaction caused by this treatment is similar to that induced by the antigen, such as viral. The virus is also an antigen for the host. Additionally, the pathway studies of viral infection are relatively more in the KEGG database. Therefore, the change in pathway exposed to $\mathrm{Cu}$ NPs is similar to viral infection. Additionally, differentially expressed genes involved in viral infection also participated in other pathways, like phagosome, cell adhesion molecules (CAMs), endocytosis, etc.

Although we have shown that the exposure of rats to $\mathrm{Cu}$ NPs for 14 days can cause ovarian injury, we also realize that this study is not without limitations. First, the chronic toxicity of $\mathrm{Cu}$ NPs on the reproductive system remains unclear. Second, we only preliminarily explored the possible mechanism of $\mathrm{Cu}$-induced ovarian damage, and the specific underlying molecular mechanism still needs further study.

\section{Conclusion}

We have demonstrated that $\mathrm{Cu}$ NPs can enter and accumulate in rat ovaries, which in turn can result in ovarian damage, follicular atresia, oxidative stress, apoptosis and apoptotic signaling activation at the protein level, and $\mathrm{Cu}$ NP-induced apoptosis involving both mitochondria-dependent and mitochondria-independent cell-death pathways. Moreover, ovarian dysfunction following exposure to $\mathrm{Cu}$ NPs may be mainly associated with steroid and hormone metabolic processes, as well as significant alterations in the expression of genes involved in apoptosis. Our findings imply that exposure to $\mathrm{Cu}$ NPs should be of concern. Therefore, caution should be exercised in the application of $\mathrm{Cu}$ NPs in various areas.

\section{Acknowledgments}

This work was supported by the National Natural Science Foundation of China (grant no 81671507), Fundamental Research Funds for the Central Universities (HUST; grant no 2015ZDTD050), and National Key Research and Development Program (grant no 2016YFC1000903).

\section{Disclosure}

The authors report no conflicts of interest in this work. 


\section{References}

1. Uauy R, Olivares M, Gonzalez M. Essentiality of copper in humans. Am J Clin Nutr. 1998;67(5 supp1):952s-959s.

2. Zietz BP, Dieter HH, Lakomek M, Schneider H, Kessler-Gaedtke B, Dunkelberg H. Epidemiological investigation on chronic copper toxicity to children exposed via the public drinking water supply. Sci Total Environ. 2003;302(1-3):127-144.

3. Galhardi CM, Diniz YS, Faine LA, et al. Toxicity of copper intake: lipid profile, oxidative stress and susceptibility to renal dysfunction. Food Chem Toxicol. 2004;42(12):2053-2060.

4. DeAlba-Montero I, Guajardo-Pacheco J, Morales-Sánchez E, et al. Antimicrobial properties of copper nanoparticles and amino acid chelated copper nanoparticles produced by using a soya extract. Bioinorg Chem Appl. 2017;2017:1064918.

5. Ashfaq M, Verma N, Khan S. Copper/zinc bimetal nanoparticlesdispersed carbon nanofibers: a novel potential antibiotic material. Mater Sci Eng C Mater Biol Appl. 2016;59:938-947.

6. Tamayo LA, Zapata PA, Rabagliati FM, et al. Antibacterial and noncytotoxic effect of nanocomposites based in polyethylene and copper nanoparticles. J Mater Sci Mater Med. 2015;26(3):129.

7. Miao H, Zhong D, Zhou Z, Yang X. Papain-templated Cu nanoclusters: assaying and exhibiting dramatic antibacterial activity cooperating with H(2)O(2). Bioinorg Chem Appl. 2015;7(45):19066-19072.

8. Hu LX, Wang H, Rao M, et al. Alterations in the endometrium of rats, rabbits, and Macaca mulatta that received an implantation of copper/ low-density polyethylene nanocomposite. Int J Nanomedicine. 2014;9: 1127-1138.

9. Hu LX, He J, Hou L, et al. Biological evaluation of the copper/lowdensity polyethylene nanocomposite intrauterine device. PLoS One. 2013;8(9):e74128.

10. Xia X, Wang Y, Cai S, Xie C, Zhu C. Will ethylene oxide sterilization influence the application of novel $\mathrm{Cu} / \mathrm{LDPE}$ nanocomposite intrauterine devices? Contraception. 2009;79(1):65-70.

11. Xia X, Xie C, Zhu C, Cai S, Yang X. Effect of implanted Cu/low-density polyethylene nanocomposite on the morphology of endometrium in the mouse. Fertil Steril. 2007;88(2):472-478.

12. Liu HF, Liu ZL, Xie CS, Yu J, Zhu CH. The antifertility effectiveness of copper/low-density polyethylene nanocomposite and its influence on the endometrial environment in rats. Contraception. 2007;75(2): $157-161$.

13. Li J, Liu Z, Li S, et al. Correlative investigation of copper/low-density polyethylene nanocomposite on the endometrial angiogenesis in rats. Front Med China. 2007;1(4):401-404.

14. Xia X, Cai S, Hu J, Xie C. Water absorption characteristics of novel Cu/ LDPE nanocomposite for use in intrauterine devices. J Biomed Mater Res B Appl Biomater. 2006;79(2):345-352.

15. Yu J, Li J, Li HG, Li JX, Xie CS, Zhu CH. Comparative study on contraceptive efficacy and clinical performance of the copper/lowdensity polyethylene nanocomposite IUD and the copper T220C IUD. Contraception. 2008;78(4):319-323.

16. Chen Z, Meng H, Xing G, et al. Acute toxicological effects of copper nanoparticles in vivo. Toxicol Lett. 2006;163(2):109-120.

17. Meng H, Chen Z, Xing G, et al. Ultrahigh reactivity provokes nanotoxicity: explanation of oral toxicity of nano-copper particles. Toxicol Lett. 2007;175(1-3):102-110.

18. Griffitt RJ, Weil R, Hyndman KA, et al. Exposure to copper nanoparticles causes gill injury and acute lethality in zebrafish (Danio rerio). Environ Sci Technol. 2007;41(23):8178-8186.

19. Griffitt RJ, Hyndman K, Denslow ND, Barber DS. Comparison of molecular and histological changes in zebrafish gills exposed to metallic nanoparticles. Toxicol Sci. 2009;107(2):404-415.

20. Prabhu BM, Ali SF, Murdock RC, Hussain SM, Srivatsan M. Copper nanoparticles exert size and concentration dependent toxicity on somatosensory neurons of rat. Nanotoxicology. 2010;4(2):150-160.

21. Liao M, Liu H. Gene expression profiling of nephrotoxicity from copper nanoparticles in rats after repeated oral administration. Environ Toxicol Pharmacol. 2012;34(1):67-80.
22. Liu Y, Gao Y, Liu Y, Li B, Chen C, Wu G. Oxidative stress and acute changes in murine brain tissues after nasal instillation of copper particles with different sizes. J Nanosci Nanotechnol. 2014;14(6):4534-4540.

23. Bai R, Zhang L, Liu Y, et al. Integrated analytical techniques with high sensitivity for studying brain translocation and potential impairment induced by intranasally instilled copper nanoparticles. Toxicol Lett. 2014;226(1):70-80.

24. Gao G, Ze Y, Li B, et al. Ovarian dysfunction and gene-expressed characteristics of female mice caused by long-term exposure to titanium dioxide nanoparticles. J Hazard Mater. 2012;243:19-27.

25. Zhao X, Ze Y, Gao G, et al. Nanosized TiO2-induced reproductive system dysfunction and its mechanism in female mice. PLoS One. 2013; 8(4):e59378.

26. Schofield CL, Marin MJ, Rejzek M, Crocker PR, Field RA, Russell DA. Detection of mSiglec-E, in solution and expressed on the surface of Chinese hamster ovary cells, using sialic acid functionalised gold nanoparticles. Analyst. 2016;141(20):5799-5809.

27. Stelzer R, Hutz RJ. Gold nanoparticles enter rat ovarian granulosa cells and subcellular organelles, and alter in-vitro estrogen accumulation. J Reprod Dev. 2009;55(6):685-690.

28. Jiang J, Wang J, Zhang X, et al. Activation of mitogen-activated protein kinases cellular signal transduction pathway in mammalian cells induced by silicon carbide nanowires. Biomaterials. 2010;31(31): 7856-7862.

29. Amorim MJ, Scott-Fordsmand JJ. Toxicity of copper nanoparticles and $\mathrm{CuCl} 2$ salt to Enchytraeus albidus worms: survival, reproduction and avoidance responses. Environ Pollut. 2012;164:164-168.

30. Wilson-Rawls J, Hurt CR, Parsons SM, Rawls A. Differential regulation of epaxial and hypaxial muscle development by paraxis. Development. 1999;126(23):5217-5229.

31. Zheng JL, Yuan SS, Wu CW, Lv ZM. Acute exposure to waterborne cadmium induced oxidative stress and immunotoxicity in the brain, ovary and liver of zebrafish (Danio rerio). Aquat Toxicol. 2016; 180:36-44.

32. Feng YM, Liang GJ, Pan B, et al. Notch pathway regulates female germ cell meiosis progression and early oogenesis events in fetal mouse. Cell Cycle. 2014;13(5):782-791.

33. Kacharmina JE, Crino PB, Eberwine J. Preparation of cDNA from single cells and subcellular regions. Methods Enzymol. 1999;303:3-18.

34. Arocho A, Chen B, Ladanyi M, Pan Q. Validation of the 2-DeltaDeltaCt calculation as an alternate method of data analysis for quantitative PCR of BCR-ABL P210 transcripts. Diagn Mol Pathol. 2006;15(1): 56-61.

35. Petersen SL, Ottem EN, Carpenter CD. Direct and indirect regulation of gonadotropin-releasing hormone neurons by estradiol. Biol Reprod. 2003;69(6):1771-1778.

36. Graham JD, Clarke CL. Physiological action of progesterone in target tissues. Endocr Rev. 1997;18(4):502-519.

37. Richards JS, Rolfes AI. Hormonal regulation of cyclic AMP binding to specific receptor proteins in rat ovarian follicles. Characterization by photoaffinity labeling. J Biol Chem. 1980;255(11):5481-5489.

38. Hockenbery DM, Oltvai ZN, Yin XM, Milliman CL, Korsmeyer SJ. Bcl-2 functions in an antioxidant pathway to prevent apoptosis. Cell. 1993;75(2):241-251.

39. Nel A, Xia T, Madler L, Li N. Toxic potential of materials at the nanolevel. Science. 2006;311(5761):622-627.

40. Wang T, Chen X, Long X, Liu Z, Yan S. Copper nanoparticles and copper sulphate induced cytotoxicity in hepatocyte primary cultures of Epinephelus coioides. PLoS One. 2016;11(2):e0149484.

41. Sarkar A, Das J, Manna P, Sil PC. Nano-copper induces oxidative stress and apoptosis in kidney via both extrinsic and intrinsic pathways. Toxicology. 2011;290(2-3):208-217.

42. Li N, Duan Y, Hong M, et al. Spleen injury and apoptotic pathway in mice caused by titanium dioxide nanoparticules. Toxicol Lett. 2010; 195(2-3):161-168.

43. Hu R, Zheng L, Zhang T, et al. Molecular mechanism of hippocampal apoptosis of mice following exposure to titanium dioxide nanoparticles. J Hazard Mater. 2011;191(1-3):32-40. 
44. Xu WN, Liu WB, Liu ZP. Trichlorfon-induced apoptosis in hepatocyte primary cultures of Carassius auratus gibelio. Chemosphere. 2009; 77(7):895-901.

45. Kumar S. Caspase function in programmed cell death. Cell Death Differ. 2007;14(1):32-43.

46. Kandasamy K, Srinivasula SM, Alnemri ES, et al. Involvement of proapoptotic molecules Bax and Bak in tumor necrosis factor-related apoptosis-inducing ligand (TRAIL)-induced mitochondrial disruption and apoptosis: differential regulation of cytochrome $\mathrm{c}$ and Smac/ DIABLO release. Cancer Res. 2003;63(7):1712-1721.

47. Yao J, Jiang Z, Duan W, et al. Involvement of mitochondrial pathway in triptolide-induced cytotoxicity in human normal liver L-02 cells. Biol Pharm Bull. 2008;31(4):592-597.

48. Suliman A, Lam A, Datta R, Srivastava RK. Intracellular mechanisms of TRAIL: apoptosis through mitochondrial-dependent and -independent pathways. Oncogene. 2001;20(17):2122-2133.

49. Tao YF, Xu LX, Lu J, et al. Metallothionein III (MT3) is a putative tumor suppressor gene that is frequently inactivated in pediatric acute myeloid leukemia by promoter hypermethylation. J Transl Med. 2014;12:182.
50. Howells C, West AK, Chung RS. Neuronal growth-inhibitory factor (metallothionein-3): evaluation of the biological function of growthinhibitory factor in the injured and neurodegenerative brain. FEBS J. 2010;277(14):2931-2939.

51. Ramji DP, Foka P. CCAAT/enhancer-binding proteins: structure, function and regulation. Biochem J. 2002;365(pt 3):561-575.

52. Sebastian T, Johnson PF. Stop and go: anti-proliferative and mitogenic functions of the transcription factor C/EBPbeta. Cell Cycle. 2006;5(9): 953-957.

53. Nerlov C. The C/EBP family of transcription factors: a paradigm for interaction between gene expression and proliferation control. Trends Cell Biol. 2007;17(7):318-324.

54. Hirai H, Yokota A, Tamura A, Sato A, Maekawa T. Non-steady-state hematopoiesis regulated by the $\mathrm{C} / \mathrm{EBP}$ beta transcription factor. Cancer Sci. 2015;106(7):797-802.

55. Tamura A, Hirai H, Yokota A, et al. Accelerated apoptosis of peripheral blood monocytes in Cebpb-deficient mice. Biochem Biophys Res Commun. 2015;464(2):654-658.
International Journal of Nanomedicine

\section{Publish your work in this journal}

The International Journal of Nanomedicine is an international, peerreviewed journal focusing on the application of nanotechnology in diagnostics, therapeutics, and drug delivery systems throughout the biomedical field. This journal is indexed on PubMed Central, MedLine, CAS, SciSearch $®$, Current Contents $\AA /$ Clinical Medicine,

\section{Dovepress}

Journal Citation Reports/Science Edition, EMBase, Scopus and the Elsevier Bibliographic databases. The manuscript management system is completely online and includes a very quick and fair peer-review system, which is all easy to use. Visit http://www.dovepress.com/ testimonials.php to read real quotes from published authors. 